\title{
Risk-sharing agreements to cover environmental damage: theory and practice
}

Citation for published version (APA):

Liu, J., \& Faure, M. (2018). Risk-sharing agreements to cover environmental damage: theory and practice. International Environmental Agreements-Politics Law and Economics, 18(2), 255-273.

https://doi.org/10.1007/s10784-018-9386-0

Document status and date:

Published: 01/04/2018

DOI:

10.1007/s10784-018-9386-0

Document Version:

Publisher's PDF, also known as Version of record

Document license:

Taverne

Please check the document version of this publication:

- A submitted manuscript is the version of the article upon submission and before peer-review. There can be important differences between the submitted version and the official published version of record.

People interested in the research are advised to contact the author for the final version of the publication, or visit the DOI to the publisher's website.

- The final author version and the galley proof are versions of the publication after peer review.

- The final published version features the final layout of the paper including the volume, issue and page numbers.

Link to publication

\footnotetext{
General rights Owners
rights.

- You may freely distribute the URL identifying the publication in the public portal. please follow below link for the End User Agreement:

www.umlib.nl/taverne-license

Take down policy

If you believe that this document breaches copyright please contact us at:

repository@maastrichtuniversity.nl

providing details and we will investigate your claim.
}

Copyright and moral rights for the publications made accessible in the public portal are retained by the authors and/or other copyright owners and it is a condition of accessing publications that users recognise and abide by the legal requirements associated with these

- Users may download and print one copy of any publication from the public portal for the purpose of private study or research.

- You may not further distribute the material or use it for any profit-making activity or commercial gain

If the publication is distributed under the terms of Article $25 \mathrm{fa}$ of the Dutch Copyright Act, indicated by the "Taverne" license above, 


\title{
Risk-sharing agreements to cover environmental damage: theory and practice
}

\author{
Jing Liu' ${ }^{1} \cdot$ Michael Faure $^{2}$
}

Accepted: 18 January 2018/Published online: 31 January 2018

(C) Springer Science+Business Media B.V., part of Springer Nature 2018

\begin{abstract}
Mordernization has witnessed increasingly new industrial sectors which have the potential to create environmental disasters. The insolvency of risk creators in case of such disasters may lead to insufficient compensation as well as to a dilution of preventive incentives. Insurance is a traditional instrument to address these problems, but is subject to limitations such as the lack of information by the insurers on the risk and limited insurance capacity. The risk-sharing agreement is an alternative which is widely used in high-risk sectors but it received relative little attention in academic literature. This paper analyses the potential of risk-sharing agreements in minimizing total social costs of environmental harmful activities, in comparison with insurance. The comparison shows the advantage of risk-sharing agreements in terms of less demanding information requirements, allowing for mutual monitoring and the potential to reduce administrative costs. However, the analysis also shows that a few conditions need to be met for such advantages to be materialized. This paper then discusses a typology of various risk-sharing agreements and illustrates the different categories with examples from the maritime and nuclear sectors. Based on these experiences, this paper explores the possibilities to expand risk-sharing agreements to other policy areas where environmental risks may emerge.
\end{abstract}

Keywords Risk-sharing agreements · Insurance $\cdot$ Oil pollution · Nuclear damage

Jing Liu

liujoyjing@163.com

Michael Faure

michael.faure@maastrichtuniversity.nl

1 The Research Institute of Environmental Law, Wuhan University, Wuhan 430072, China

2 Maastricht University/Erasmus University Rotterdam, Maastricht/Rotterdam, The Netherlands 


\section{Introduction}

Modernization has created a risk society, where environmental risks have become a common part of our life (Beck 1992a, b; Shrivastava 1995). Many industrial sectors are, on the one hand, crucial components to support the economic social development and, on the other hand, have the potential to create catastrophic damage. For example, the nuclear and oil industry play an important role in energy provision, and at the same time, they have experienced significant accidents. For example, the Deepwater Horizon accident in 2010 has caused approximately five million barrels of oil leakage. ${ }^{1}$ The Chernobyl disaster of 1986 and the Fukushima accident of 2011 also reminded people the potentially devastating effects of environmental disasters. ${ }^{2}$ These catastrophes have created a challenge for risk creators in providing sufficient compensation. Some of the polluters, like BP, have a deep pocket to cover the damage. However, a major accident may well dwarf the financial capacity of smaller companies. ${ }^{3}$ The Fukushima accident also shows that even a deep pocket may not be sufficient when an operator is facing a major nuclear accident. ${ }^{4}$ The insolvency of risk creators may lead to both insufficient compensation and may dilute preventive incentives. ${ }^{5}$

Insurance is the traditional instrument used to remedy insolvency problems. The insured can shift its risk to a less risk-averse insurer at the price of premium. The insurers calculate an actuarial premium based on the information on the probability and the extent of the potential harm and pool large numbers of risks together. ${ }^{6}$ Therefore, it can provide coverage to future risks. However, the development of many high-risk sectors has challenged the capacity of insurance. The capacity of insurers to take over risks builds upon the possibility to calculate the actuarial premium. However, high uncertainties exist with many industrial sectors, such as the nuclear or oil sector, where the probability and extent of the damage are very difficult to estimate. For many newly emerging sectors, such as carbon capture and storage, information also needs to be accumulated through time (Faure 2016, pp. 448-455). The lack of information makes the ex ante calculation of an actuarial premium impossible. Moreover, an industrial catastrophe may cause damage which

\footnotetext{
${ }^{1}$ National Commission on the BP Deepwater Horizon Oil Spill and Offshore Drilling, The Amount and Fate of the Oil, Working Paper No. 3. <http://www.oilspillcommission.gov/sites/default/files/documents/ Updated\%20Amount $\% 20$ and $\% 20$ Fate $\% 20$ of $\% 20$ the $\% 20$ Oil $\% 20$ Working\%20Paper.pdf.

${ }^{2}$ Both accidents are rated seven on the International Nuclear Event Scale (INES), the highest level of nuclear events. The INES was introduced in 1990 by the International Atomic Energy Agency (IAEA) to communicate to the public the safety significance of nuclear and radiological events. The INES scale explains the significance of events arising from a range of activities, such as the industrial and medical use of radiation sources, operations at nuclear facilities and transport of radioactive material. Events are classified on the scale at seven levels. The severity of an event is about ten times greater for each increase in level on the scale. See the website of IAEA: http://www.iaea.org/Publications/Factsheets/English/ines.pdf (last visited Mar. 10, 2012).

3 A major offshore accident can put smaller and middle-sized operators out of business. Interview with representatives of Noble Energy, on 6 March 2013.

4 The Tokyo Electric Power Company (TEPCO), a large electricity company in Japan was not able to cover the damage caused by the Fukushima accident. The government hence established a nuclear damage compensation facilitation corporation to cover the damage. This corporation is financed via contributions from all nuclear operators in Japan. See, Faure and Liu (2012, pp. 189-201).

5 Economic analysis of law shows that if the insolvency combines with strict liability, risk creators will have only incentives to prevent damage up to its solvency level, hence leading to under-deterrence. See Visscher (2009, pp. 156-158).

6 Wagner (2009, pp. 377-378).
} 
outweighs the capacity of insurers. In this situation, alternatives to insurance are crucial for the prevention and compensation of environmental damage.

The risk-sharing agreement is one type of such instruments which has been widely used in high-risk sectors but has attracted little attention. Similar as with insurance, risk-sharing agreements cover environmental risks via pooling. However, under such agreements, it is the risk creators, but not commercial insurers that aggregate resources to provide coverage for their own risks (Doucette 2002). Risk-sharing agreements are also referred as risksharing institutions (Faure 2004; Faure and Skogh 1992; Skogh 1999, 2008) or mutuals (Bocken 2009). In this contribution, we will use those three terms interchangeably. Note, however, that when we refer to pools we are always aiming at risk sharing between operators, not pooling between insurance companies (for which this notion of pooling is sometimes used as well). ${ }^{7}$

This article sketches the theory and practice of risk-sharing agreements for environmental damage. Many operators have developed (e.g. marine oil pollution and nuclear damage) a variety of different risk-sharing agreements. This article argues that those risk-sharing agreements play an important role in providing ex post compensation, but can equally, via the mutual monitoring inherent in risk pooling contribute to efficient prevention. Risk sharing may thus be especially attractive in case of new technologies (e.g. carbon capture and sequestration) where operators themselves may be in the best position to assess the risk and hence to impose preventive measures via mutual monitoring. However, it is worth noting that a relative homogeneity of the risks involved is crucial for the successful functioning of risksharing pools. Too great heterogeneity may prevent the emergence of a risk-sharing pool or lead to cross-subsidization and hence create suboptimal deterrent incentives.

The remainder of this contribution is set up as follows: after this introduction, (1) we sketch the basic theory of risk sharing (2) and then explain the working of various risksharing agreements and provide examples of different types of pools (3). We then proceed to a policy analysis (4) and formulate a few concluding remarks (5).

\section{Risk sharing: basic theory}

\subsection{Goal of risk-sharing agreements: minimizing total social costs}

A risk-sharing agreement is an important compensation instrument used to cover environmental damage, including both damage suffered by the risk creators themselves and to cover third-party liability. To analyse its functioning and to compare it with traditional insurance, a benchmark for analysis needs to be chosen. This research uses the analytical framework developed by Guido Calabresi (Calabresi 1970). Calabresi argues that liability rules should generally aim at a minimization of the total social costs of accidents. He distinguishes between so-called primary, secondary and tertiary costs. The primary accident costs are the costs of accident avoidance and the accident costs. To minimize primary costs requires weighing the marginal costs of additional preventive measures versus the marginal benefits in a reduction of the accident risk. ${ }^{8}$ Secondary costs are the costs of risk spreading, which requires risk spreading or the primary costs to be shifted to the less riskaverse party (Calabresi 1970, pp. 27-28). The tertiary costs are referred to as

\footnotetext{
7 See generally on pooling by insurers Faure and Hartlief (2003, pp. 90-94).

8 This point has been further worked out by Shavell S, 'Strict Liability versus Negligence' 9 The Journal of Legal Studies 1 (1980).
} 
administrative costs or more generally the costs of administrating the compensation system (Calabresi 1970, pp. 28-29).

Though this framework is developed for analysing liability rules, it can also act as a yardstick in evaluating compensation instruments. Economic analysis has shown that liability rules have their limitations in achieving these goals alone, due to information asymmetry, the insolvency of liable parties, low probability to be sued and so on (Shavell 1984; Faure and Grimeaud 2003). Therefore, compensation instruments can act as a remedy to achieve the goal of social cost minimization (Liu 2013, pp. 87-90). This section compares the capacity of risk-sharing agreements and insurance in reducing the three types of social costs. ${ }^{9}$

\subsection{Insurance versus risk-sharing agreements}

One commonality between risk-sharing agreements and insurance is that both can be used to pool risks and to increase the utility of risk-averse parties. Insurance is a commonly used risk transfer instrument, which allows the party initially bearing risk (insured) to shift the risk to another party less risk-averse or more able to bear it (insurer) (Wagner 2009, p. 377). ${ }^{10}$ It is important to calculate the actuarially fair insurance premium to cover the insured risks, which should equal the expected accident costs, this is represented by the probability multiplied by the possible magnitude of the damage once the accident has occurred (Croley and Hanson 1995, note 27). In addition, in the actual insurance market, administrative costs and profit of insurance industry need to be added in determining the real premium. ${ }^{11}$ Whether the premiums charged above the level of actuarially fair premium is acceptable for the insured depends on the strength of the risk-aversion and the associated willingness to pay to transform risk into certainty (Wagner 2009, p. 378). Relatively smaller operators with few assets may have a higher demand for protection especially against the risks of being exposed to large losses, especially those that could largely outweigh their individual assets and hence wipe out their existence. Larger operators with substantial assets may to the contrary largely rely on their balance sheet to cover risks. ${ }^{12}$

According to a mathematic theorem, 'the law of large numbers', 'in repeated, independent trials, with the same probability of a particular outcome in each trial, the actual incidence of that particular outcome will converge more closely with the probability of that outcome as the number of trials increases'. ${ }^{13}$ Therefore, by pooling a large amount of

\footnotetext{
${ }^{9}$ For a further analysis of the comparative benefits of pools, see also Liu (2013, pp. 137-142).

${ }^{10}$ A risk-averse party prefers to choose a certain loss of premium (say 1000) rather than a possibility of larger loss in case of accidents (e.g. a lottery with a 10\% chance of losing 10,000). Therefore, insurance can be used to improve the utility of the insureds.

11 Faure and Hartlief (2003, pp. 84-85). For example, in the case discussed earlier, the actuarially fair premium is presented by the probability of 0.1 multiplied with the magnitude of the loss of 10,000 , being 1000. However, the premium charged may amount to 2000, considering the administrative costs and profits of the insurance company.

12 That explains why, e.g., BP did not seek ex ante cover for potential damage from offshore accidents but relied on self-insurance. In the case of Deepwater Horizon, BP self-insures through its own capacitive insurance company, Jupiter Insurance, which relies on BP's own balance sheet and does not purchase reinsurance. See Bosma (2012, pp. 108-109).

13 Wagner (2009, pp. 382-383). A common example is the rolling of a dice. A single roll of a six-sided die produces one of the numbers 1-6, with equal probability. Thus, the expected value of a single roll is $(1+2+3+4+5+6) / 6=3.5$. With limited trials, the results can depart sharply from the expected value. However, repeated in large numbers, the average outcome approaches 3.5 .
} 
similar but independent risks, insurers can make the probability of the realization of risks and their magnitude more predictable.

For the insurance market to operate, the risks should be insurable. In other words, the risk needs to satisfy some minimum requirements in order to be eligible for insurance coverage. In spite of the variance in formulation, ${ }^{14}$ an insurable risk usually should be as follows: accidental, determinable and measurable, independent and non-catastrophic (Wagner 2007, p. 89). Accidentalness requires that the loss 'be contingent upon a move of nature and not the result of a deliberate choice by the insured' (Wagner 2009, p. 400). Otherwise, the insured can influence the insurer's obligation at their own will, which can lead to wrong incentives to the insured. The requirements of determinability and measurability are essential for setting the premiums of insurance. As mentioned earlier, the calculation of premium gives high information requirements on both the frequency and the severity of losses. A well-defined risk, the existence of empirical data and explicit measurement methodology can help to obtain such information. Besides, an insurable risk must be independent rather than cumulative, which means that the materialization of one risk does not increase the probability of the realization of a significant portion of the other risks. Otherwise, the simultaneously happened accidents may easily lead to the insolvency of the insurers. The limited financial capacity of insures also imposes the requirement of noncatastrophic damage. The independence and non-catastrophic nature of losses are often interrelated. The modest and manageable single damage may pile up to be unmanageable if numerous people are simultaneously negatively affected (Faure and Bruggeman 2008). ${ }^{15}$

For environmental risks, especially those created by high-risk sectors or new sectors, the insurability requirements are not always easy to satisfy. For example, determinability and measurability require information concerning the probability and potential extent of the damage. However, many sectors have the potential to cause very low probability but catastrophic accidents, such as the nuclear and offshore oil exploration sectors. Due to the low frequency, few data have been accumulated, and an accurate estimate of both the probability and the magnitude of the accident is extremely difficult. The high-speed technology development brings new sectors with environmental risks ${ }^{16}$ or renews the current industrial structure and hence changes their risks ${ }^{17}$ every day, also adding to the difficulties in measuring the risks. Moreover, according to the law of large numbers, a large amount of samples is crucial for the estimation of risks, which, may not exist for many

\footnotetext{
14 According to Katzman, insurable risks have those characteristics: exposures must be homogeneous and numerous enough to allow risk pooling; the loss occurs within a well-defined time period; and the frequency and severity of loss are calculable for premium setting; Katzman (1986, p. 617). Anderson gave a list of prerequisites of ideally insurable risks: a large number of units are independently and identically exposed to the risk, the loss is determinable and calculable, the loss is fortuitous or accidental and not subject to simultaneous destruction. Anderson (1998, p. 2).

15 This exacted the problem for many risks concerning natural disasters, such as flooding risks and earthquake risks. The materialization of risks will lead to many households subject to damage, piling up to catastrophic damage.

${ }^{16}$ For example, in response to the pressure in mitigating green house gas emission, carbon capture and storage was developed as an alternative, which can capture, transport and store $\mathrm{CO} 2$ for a long period of time. See Klass and Wilson (2008). However, this technology can create environmental risks as well, such as the leakage of $\mathrm{CO} 2$, negative impact on drinking water aquifers in sequestration sties, creating seismic risks and potential injury to persons and the environment. See Bode and Jung (2006, p. 180), Adelman and Duncan (2011, pp. 4-8), Wilson et al. (2003, p. 3477, 2009, p. 4576).

17 Nuclear power stations have been developed since the 1950s. After more than half a century's development, the capacity of the insurance market to cover nuclear risks are still limited. The evolving nuclear technology makes the corresponding risks ever changing as well. See Ameye (2010, pp. 44-50).
} 
environmental risks. ${ }^{18}$ Besides, history has also witnessed accidents resulting in tens of billions dollars losses. The potential catastrophic nature also questions the insurability of the risks.

Many instruments have been adopted to complement insurance in case of uninsurability, such as environmental funds and the use of capital markets. Risk-sharing agreements are one of those commonly adopted instruments. It resembles insurance in pooling risks. However, a major difference is that under an insurance policy risks are shifted to a third party (the insurance company); whereas in a risk sharing scheme, the operators are both insured and insurer; there is hence no involvement of a third party (Skogh 1999, pp. 510-511). Because risks are shifted to insurance companies, in insurance the premium needs to be determined and charged ex ante. For a risk-sharing agreement, however, because risks are only shared among members but not transferred to third parties, an ex ante agreement on ex post sharing of losses is sufficient. Ex ante calculation and payment of premium is no longer necessary.

The remainder of this section compares the potential of risk-sharing agreements to insurance in their capacity in reducing total the social costs of accidents.

\subsection{Primary cost reduction: less information needed}

To minimize the primary costs requires that the potential injurers are given optimal incentives to reduce the accidents. This means the contributions potential injurers have to pay should be aligned to the risks they create. In other words, the premiums paid by insureds under an insurance policy or the contributions made by risk creators under a risksharing agreement need to reflect the actual costs they produce. To determine the premium/contribution, accurate risk-related information is important. If insurers or the pooling institution has no information to determine the correct premium/contribution, risk creators can take advantage of information asymmetry and the problems of moral hazard and adverse selection may emerge (Wagner 2009, pp. 388-393). Moral hazard means that the risk creators' motive to prevent loss tends to change after obtaining the coverage, since the risk of paying large amount of losses is removed (Shavell 1979, p. 54; Wagner 2007, p. 95). Adverse selection refers to 'the tendency of persons with relatively greater exposure to risk to seek insurance protection' (Priest 1987, p. 1541). In a well-functioning insurance market/pooling system, the average premium/contribution should be aligned with the risk profile of most members in a particular pool. However, if the risk different insured possess varies significantly, the good risks whose expected damage is less than the premium/contribution will leave the pool. Only the members with a higher risk have strong incentives to stay.

The above analysis shows the importance of information in creating the right preventive incentives for insurance and risk-sharing pools. However, such information is not always available, especially when new risks are concerned. This creates a problem of insurer ambiguity. Insurers will deal with that by charging a risk premium. However, if insurers (due to their lacking information) assess the project as risky and thus charge a relatively high-risk premium, the insured may perceive this differently and thus have no willingness

${ }^{18}$ For example, in the nuclear sector, there are worldwide 444 nuclear reactors operating by July 2016. About 100 reactors are operating in a major nuclear country, the USA. But in most other countries, the number of nuclear reactors is limited. For an overview of nuclear reactors in operation, see the update of World Nuclear Association, http://www.world-nuclear.org/information-library/facts-and-figures/worldnuclear-power-reactors-and-uranium-requireme.aspx. Another example is the CCS Projects. In spite of the broad interests, there have been no commercialized CCS Projects yet. See Faure (2016, p. 395). 
to pay this higher premium. ${ }^{19}$ As a result of a lacking demand for those (relatively high) risk premiums, a market will not emerge and that is why new risks are often considered as 'uninsurable'.

Unlike in the case of commercial insurance, where ex ante information about the probability of a certain risk and its magnitude should be available to allow the calculation of an ex ante charged premium, in a risk-sharing agreement policy, each member's contribution can be agreed upon on beforehand and only actually paid ex post. This characteristic makes it possible for a risk-sharing agreement to deal with uncertain risk, for which the statistical data about the occurrence are rare or the probability and size are less predictable. As long as a risk differentiation can be made among the members, a risksharing agreement can be feasible, since an ex ante charging of premiums is not necessary. Only the relative contribution of each member to the risk has to be known. ${ }^{20}$

\subsection{Primary cost reduction: mutual monitoring}

In addition to determining risk-based premiums, monitoring either by insurers or other parties in the risk pool is also crucial to ensure the deterrent effect. For example, even when risk-based premiums have been charged, moral hazard may lead covered members to take excessive risks. Monitoring hence is crucial to ensure that the desirable precaution is actually taken.

The monitoring measures under insurance and a risk-sharing agreement operate differently. Under insurance policies, it is the insurer that monitors the behaviours of insured. In a risk-sharing agreement, mutuality is created whereby the contribution paid by one member depends on the claims made by all other members (Bennett 2001, p. 15). It is in the interests of all other members' claims to be as low as possible, and thus a mutual interest of risk minimization is created (Bennett 2001, p. 15). To reduce risks, the members of such a group have incentives to differentiate risks. That will imply to align a member's contribution to the risk that each member poses and to monitor each other. A certain level of trust is crucial to build this mutuality. Therefore, members in a risk-sharing pool usually possess similar risks, common knowledge of possible moral hazard, repeated exchanges, subject to similar reputation and other social control (Skogh 1999). The members are faced with the same type of risk and have often more expertise and precise knowledge compared to a third-party insurer (Faure and Fiore 2008, p. 302). Therefore, they can evaluate the risk each member creates and can better monitor each other's behaviour.

\subsection{Secondary cost reduction: lower costs and prices}

Insurance and risk-sharing agreements also play a role in reducing secondary costs via spreading risks among multiple parties. Individuals can share the risks with other parties in the same insurance/risk-sharing pool via the payment of premiums/contributions. The premium and contribution payment, however, may lead to different costs.

In an insurance policy, the risk is shifted to the insurer at the price of a premium. The premium is not recoverable by the insured no matter whether the insured risk is

\footnotetext{
19 See on the calculation of those risk premiums Hogarth and Kunreuther (1985).

${ }^{20}$ Suppose that various parties involved in shale gas fracking would pool. Pooling is possible as long as the members know, e.g. that installation A poses a higher risk than installation B. That simply means that A will have to contribute more to the pool than B, even if the precise probability of the risk for neither A nor B is unknown.
} 
materialized or not. To finance the risk-sharing pool, the operators can either make advance payments or make an ex ante agreement to pay retrospective premiums after the damage (Faure and Fiore 2008, pp. 301-302). If the pool members make an advance payment, the contributions can be carried over for the following year if there is no accident. A member can also recover his contribution by stopping, creating the risk and leaving the pool (Faure and Fiore 2008, pp. 301-302). Therefore, he will not lose his contribution if no accident happens.

Under the retrospective premium model, the obligation to make contribution is postponed until the accident happens. Since contributions do not have to be paid up front, risk pooling does not necessarily lead to immobilization of capital, which can therefore still be used for other social useful activities. Of course such a risk pooling based merely on a mutual commitment between the parties supposes more than mutual trust: there should be an adequate control, also on the solvency of the members in the pool, in order to avoid free-riding, moral hazard and negative redistribution. ${ }^{21}$

\subsection{Tertiary cost reduction}

Besides the potential to reduce primary costs and secondary costs, a risk-sharing agreement also creates tertiary costs. The agreement is usually established among members of the same sector who are producing the same types of risks. Compared to a third-party insurer, the potential injurers themselves possess better knowledge about the potential risks, methods of risk assessment control, as well as mutual monitoring. In this sense, the risksharing agreement can help to keep the costs to operate such a compensation mechanism lower, compared to insurance. However, this benefit needs to be balanced against the advantages of insurance, since insurers are specialized in dealing with risk. Moreover, these costs advantages of risk sharing may only materialize if risks are shared between a relatively small number of operators, all creating or exposed to similar risks.

\subsection{Summary}

The above analysis shows that insurance and risk-sharing agreements can both be used to pool environmental risks. However, their potential to reduce the total social costs of accidents is different, especially concerning highly technical and complicated sectors. For such sectors, risks operators themselves may have better information (compared to insurers) on optimal preventive technologies and thus to determine correct, risk proportional contributions. Risk-sharing agreement is also less information demanding than insurance, since the ex ante requirement of information as both the probability and the magnitude of losses is no longer necessary. Information over the relative contribution of each member to the risk is sufficient. Besides, risk-sharing agreements also create strong incentives for mutual monitoring. The information advantage and mutual monitoring incentives contribute to the capacity of risk-sharing agreements to reduce primary costs. In addition, risk-sharing agreements also have the advantage in reducing secondary costs by postponing the payment obligation till damage happens and resulting in losses of contribution only when accidents happen. However, such a risk-pooling mechanism may have all these advantages if the number of members in the pool is relatively restricted; the comparative benefit (compared to insurance) mostly applies to highly technical (new) risks. In those cases, operators may have a clear information advantage compared to insurers.

${ }^{21}$ Such examples are further elaborated by the examples of OPOL and the America nuclear pooling system, in Sect. 3. 
When, however, the members of the pool would be very large (e.g. all car drivers in a particular area) the administrative costs of running the pool would become huge and the comparative benefits vis-à-vis insurance would disappear.

\section{Different types of pools}

After examining the advantages of risk-sharing agreements compared to insurance in covering risks where information on probabilities and damage is often lacking, we will now sketch different types of risk-sharing agreements. Risk-sharing agreements can be classified according to different criteria, such as the risks it covers (environmental risks vs. insolvency risks) and the way of payment (ex ante payment vs. retrospective premiums). This section sketches briefly the typology of risk-sharing agreements (3.1) and then provides some examples of pools for vessels-induced oil pollution (3.2), offshore oil pollution (3.3) as well as nuclear damage (3.4).

\subsection{Typology of risk-sharing agreements}

Risk-sharing agreements can have different institutional arrangements. For example, they may cover different risks: either damage to their members' own property ${ }^{22}$ or the damage to third parties. ${ }^{23}$ The risk-sharing agreements can also be mandated by ${ }^{2} \mathrm{w}^{24}$ or be established based on a voluntary contract between its members. ${ }^{25}$ Many different criteria can be used to classify risk-sharing agreements, and this section focuses on the categories made according to two criteria: whether it covers environmental risk itself or only the insolvency risk. Another criterion relates to the way in which the members contribute to the pool.

Typical risk-sharing agreements (mutuals) pool environmental risk together and provide coverage when covered risks materialize. ${ }^{26}$ Such examples can be found both for the maritime risk ${ }^{27}$ as well as for the first party (damage) cover for the nuclear risk. ${ }^{28}$ In those cases, the risk-sharing agreement actually functions as insurance. The main difference constitutes the fact that the risk is not shifted to a third party (insurer) but that operators mutually share each other's losses.

A second type of risk-sharing agreement does not necessarily provide coverage when the accident happens and environmental risks materialize. The environmental risks are

\footnotetext{
22 Oil Insurance Ltd is such an example. It provides coverage for physical damage, costs of well control and third-party liability for offshore oil facilities. For the discussion of OIL, see Faure et al. (2015, p. 389).

23 See infra the example of OPOL.

24 Such as the example of the American nuclear pooling system mandated by the Price-Anderson Act. See section 3.4.1.

25 The nuclear pool in Germany is such an example, which is established by nuclear power plants to cover their potential liability. For details, see Pelzer (2007) and Carroll (2008).

${ }^{26}$ In this case, risks are directly shared among pooling members. This arrangement creates a mutual interest between members in minimizing risks. The risk-sharing institutions discussed by Skogh fall into this type. See Skogh (2008). For the discussion about mutuality, see Bennett (2000, 2001).

27 Such as the P\&I Clubs. See Sect. 3.2.

${ }^{28}$ For example, in the USA, regulation requires nuclear power plant operators to obtain insurance or demonstrate their financial status to cover property damage up to 1.06 billion USD. To satisfy such requirements, the operators established a mutual risk-sharing system, Nuclear Electric Insurance Limited (NEIL). For details, see Liu (2013, pp. 246-247).
} 
firstly covered by other financial guarantee measures, such as insurance on bank sureties. Only in case the polluter and its first layer financial guarantors fail to cover the full damage, the risk-sharing pool will intervene. In this case, the risk-sharing agreements actually provide coverage for the insolvency risk of individual members and their financial guarantors, rather than for the environmental risks themselves. ${ }^{29}$

In addition, risk-sharing agreements can also differ according to the time of payment. The members can make anex ante payment ${ }^{30}$ to the pools and adjust the contribution ex post after the actual damage happens. They can, however, also agree to postpone the payment until the emergence of damage. This is called a retrospective pooling scheme. In this case, sometimes measures are taken to ensure that the members will be solvent to pay for the retrospective premiums. ${ }^{31}$

These various functions of different risk-sharing agreements can be illustrated as follows:

\subsection{Example: pools for vessel-induced oil pollution (P\&I Clubs)}

One example of a mutual risk-sharing agreement from the maritime area is provided by the so-called Protection and Indemnity Clubs (abbreviated as P\&I Clubs). A P\&I Club is a non-profit making mutual insurance association which is established by ship owners and charterers to cover their third-party liabilities related to the use and operation of ships.

The first English Protection Associations were founded in the mid-nineteenth century in Britain. Following the development of those associations in Britain, P\&I Clubs began to grow in the late nineteenth and early twentieth century in Scandinavia and America as well (Libby 1952, p. 171). The International Groups of P\&I Clubs (the P\&I Group) has been formed on the basis of individual P\&I Clubs. Its thirteen member clubs provide liability cover for approximately $90 \%$ of the world's ocean-going tonnage.

P\&I policies cover the liabilities specifically enumerated in the agreement-the Club's rulebook. P\&I Clubs provide broad coverage for the liability that marine going vessels face. ${ }^{32}$ To cover such risks, the P\&I Clubs pool their claims together through a pooling agreement and formed the International Group of P\&I Clubs (hereinafter the Group). The 'pooling agreement' defines the pooled risks and the allocation of losses between the participating clubs. ${ }^{33}$ The current pooling agreement makes US\$3.1 billion available to cover the potential liability. ${ }^{34}$ Among this amount, the limit for compensation for oil

\footnotetext{
29 OPOL is such an example.

30 The example of P\&I Clubs combines ex ante and ex post payment.

31 See infra the example of the US nuclear pool.

32 Its coverageusually includes reimbursement for claims arising from: liabilities in respect of persons, liability in respect of cargo, collision with ships, or with fixed and floating objects, salvage, compulsory wreck removal, fines imposed by government agencies, quarantine expenses, towage liabilities, "sue and labour" and legal costs, any other liabilities which the club's directors deem proper to cover as well as reimbursement for oil pollution claims which arise from the entered vessels. Ronneberg (1990, pp. 7-9). Ronnerberg's analysis was based on the Swedish Club's 1990 rulebook. A similar coverage can also be found in the 2010 rulebook of the United Kingdom Mutual Steam Ship Assurance Association (Bermuda) Limited (Bermuda Rulebook). In the rulebooks, the "unlimited" reimbursement does not mean that the Club should pay the full costs which fall into the categories. Instead, the reimbursement is subject to the limitation of liability set by law. While for oil pollution claims, the compensable sums are determined by the Directors of the Club. See Rule 5, B of the Bermuda Rulebook, http://www.ukpandi.com/ukpandi/resource.nsf/Files/ 2010Rules/\$FILE/2010Rules.pdf.

33 http://www.igpandi.org/group-agreements.

34 http://static.igpandi.org/igpi_website/media/adminfiles/pandi-RIa.pdf.
} 
pollution is limited to $\$ 1$ billion. ${ }^{35}$ The clubs often have rules on warranties and exceptions. Non-compliance with the rules can restrict or reduce claims against the club by the members. Such warranties and exceptions usually refer to the payment of calls (comparable to a premium), the necessity for vessels to remain in their class, compliance with vessel surveys, seaworthiness and so on (Hazelwood and Semark 2010, pp. 196-227).

In order to assess and control risks, the P\&I Clubs require an applicant to disclose riskrelated information on new entries or renewals. Usually remaining 'classed with a classification society approved by the managers' is a precondition for vessels to be covered by the clubs (Hazelwood and Semark 2010, p. 70). The clubs also require members to notify the classification society of any incident with the potential to give rise to damage and to comply with the rules, recommendations and requirements imposed by their classification societies. Many clubs also require additional surveys to be conducted either by themselves or by independent surveyors when vessels apply for entry. Such surveys often demand more stringent conditions than the classification societies (Hazelwood and Semark 2010, p. 70). Different from classification societies, which focus on the seaworthiness of vessels, the club surveys are more interested in the 'condition of the vessel as a potential source of liabilities; for example, its ability to carry cargo or passengers or crew carefully' (Hazelwood and Semark 2010, p. 70). Based on the surveys, the clubs decide whether to reject or accept the vessels with a 'Defects Warranty' whereby any claim arising out of defects noted during the survey would be excluded from the cover (Hazelwood and Semark 2010, p. 38). In case a 'Defects Warranty' is issued, the vessel needs to undergo further surveys to ensure the remediation of the defects. Recently, the clubs can also introduce operating guidelines for the management and running of vessels (Hazelwood and Semark 2010, p. 38).

In a P\&I Club, the ship owners make contributions to a risk pool according to an ex ante agreement. Different from traditional insurance, under which premiums need to be paid ex ante, the contribution/premium for P\&I Clubs is 'an agreement that each member should bear his aliquot share of the losses of the year covered by the policy'. ${ }^{36}$ The premium is levied through calls. Before the beginning of each year, club managers estimate the claims and expenses for the year and decide a proportion of the total to be called up as an 'advance call'. The remaining proportion will be collected via supplementary calls (Hazelwood and Semark 2010, p. 104). The clubs have made it clear that estimation of supplementary calls does not prevent them from levying a higher or lower amount (Hazelwood and Semark 2010 , p. 104). The members are 'obliged to pay the supplementary call to the extent the advance call is insufficient to cover the claims' (Zhu 2007, p. 177). In a catastrophic year, if the total claims exceed the amount that is 'recoverable in respect of that claim under the Group Excess Reinsurance Policies', payment can be paid from the Catastrophe Reserve Fund. In the case that this fund is insufficient, an overspill call will be levied (Zhu 2007, p. 105). In this way, the P\&I Clubs combine an ex ante payment with a retrospective payment. The advance call is announced at the beginning of each policy year, but the payment can be made by instalments during the year. Supplemental and overspill calls are collected ex post.

The essence of the P\&I Club is that the ship owners are members of the club. Hence, they are, in principle, not considered clients (as within an insurance company) but rather as members, thus having a very close relationship to the club. Different from traditional insurers, P\&I Clubs underwrite on a cost but not profit basis, which means that it follows

\footnotetext{
35 http://static.igpandi.org/igpi_website/media/adminfiles/pandi-RIa.pdf.

36 Williams v. The British Marine Mutual Insurance Company (1886), 6 Asp MLC 134 at, 136.
} 
the equation that 'calls plus investment income should equal claims plus expenses plus reinsurance premiums' (Zhu 2007, p. 98). The amount of each advance is based on the ship owners' claims history, the size of the fleet, the club's anticipated needs and the strength or profitability of the insurance market (Ronneberg 1990, p. 29; Hazelwood and Semark 2010, p. 95). In other words, the Clubs try to tailor the premiums to the risks the vessels are exposed to.

It is worth noting that a P\&I Club provides more services than a pure insurer and operates as a mixture of an insurance company, a law firm and a loss adjuster. Besides offering an insurance coverage, a P\&I Club can also provide a worldwide network of correspondents and representatives to give on-the-spot assistance to the shipowner when required, give Letters of Undertaking to offer a security when members' vessels are arrested and assist in claims handling and settlement (Ronneberg 1990, pp. 25-29).

\subsection{Example: pools for offshore oil pollution}

Offshore oil exploration and exploitation is also becoming an important sector and has the potential to create substantial environmental harm. The Offshore Pollution Liability Agreement (OPOL) provides an excellent example of a pool for insolvency risks (Faure and Wang 2015). OPOL is created by the Offshore Pollution Liability Association, an oil industry body which has been set up as a company limited by guarantee. It originated in the UK and came into effect on the first of May 1975 as an agreement between all UK offshore operators. ${ }^{37}$ The reason for creating OPOL was that at the time, operators anticipated that there may be a convention or a regulatory duty that would be created. In the end, the convention never came, but OPOL lasted. ${ }^{38}$ In the UK, membership of OPOL is a condition for the granting of a licence by the government. ${ }^{39}$ OPOL has extended to cover offshore facilities in the North Sea and currently has 126 members. ${ }^{40}$ OPOL not only is a risk-sharing pool, but it also provides means of compensation and reimbursement. ${ }^{41}$ It establishes a duty to compensate pollution damage based on a strict liability rule. ${ }^{42}$

OPOL provides compensation up to $\$ 250$ million per incident. ${ }^{43}$ In case of insolvency of one of the members or if a member for other reasons fails to meet its obligations, all remaining members to OPOL agree to contribute, in proportion to the number of relevant offshore facilities operated by it on the date of the incident in question, towards payment of claims due from a party that fails to meet its obligations. ${ }^{44}$ In other words, the contribution is not risk-related and OPOL lacks the benefits of mutual monitoring.

Since OPOL only intervenes in case of insolvency, it is important for members to provide financial responsibility. ${ }^{45}$ The operator may use different ways of proving financial

\footnotetext{
37 http://www.opol.org.uk/index.htm.

38 Interview with representatives of OPOL on 27 March 2013 in Brussels.

39 Id.

40 OPOL, Report and Financial Statements for the year Ended 31 December 2014 (hereinafter 2014 annual report), at 2, available at http://www.opol.org.uk/downloads/OPOL\%20Signed\%20Financial\% 20Statements\%20-\%2031\%20December\%202014.pdf.

41 Preamble of Offshore Pollution Liability Agreement (OPOL Agreement), as amended 1December 2015.

42 Clause IV, A, OPOL Agreement.

43 Clause IV, A, OPOL Agreement.

44 For more details on the pooling function of the OPOL, see infra section III.E.

${ }^{45}$ Form B of OPOL.
} 
responsibility, including insurance, a surety bond, a guarantee provided by qualified guarantors or a financial statement provided by the members or their parent company. ${ }^{46}$

It is worth noting that until now never a default of the operator took place as a result of which the guarantee clause in the OPOL agreement would come into effect. ${ }^{47}$ Of approximately 80 companies in the UK who have provided OPOL with details of financial responsibility currently in place, four companies use a company guarantee and hence rely on credit rating of the guarantor. All but four members of OPOL show financial responsibility for operations in the UK via insurance. ${ }^{48}$

\subsection{Example: pools for nuclear damage}

The nuclear sector has also the potential to create low probability and catastrophic damage, challenging the capacity of the commercial insurance market. A few mutual pools have been created to cover either the first-party property damage or third-party liability caused by the nuclear industry in the USA and Europe. Examples constitute the Nuclear Electric Insurance Limited (NEIL), ${ }^{49}$ the European Mutual Association for Nuclear Insurance $(\text { EMANI })^{50}$ as well as the European Liability Insurance for the Nuclear Industry (ELINI). ${ }^{51}$ Since mutuals have been discussed within the context of the maritime sector in further detail, this section focuses on another type of pooling: risk pooling via retrospective premiums.

\footnotetext{
46 Information for Prospective Members, 2, available at www.opol.org.uk/downloads/opol-memberinfojan14.pdf. All these forms are available at the website of OPOL, www.opol.org.uk/forms.htm.

47 Annual report 2014, the reports systematically mention "no incident requiring the operation of clause III. 2 of the agreement occurred during the year".2014 annual report, at 2.

48 Ibidem.

49 NEIL is a pool created by US nuclear operators to cover their property damage to satisfy their obligation to provide financial guarantee under governmental regulations. The operators need to pay annual premiums ex ante based on the amount of coverage, the deductible and various rating criteria. Based on the principle of "equitable treatment", members are provided with the same coverage, subject to the same loss control standards and requirements. The requirement to be a member of a self-regulatory institution in the USA, the Institute of Nuclear Power Operations (INPO) helps to make the risks comparable among members. If INPO decides that a site does not satisfy certain standards, the premiums will be increased accordingly. In case of excessive damage, retrospective premiums will be collected. For the details on NEIL, see Liu (2013, pp. 246-247).
}

50 EMANI is based in Brussels and provides coverage for material damage, business interruption, machinery breakdown, terror and all risk for nuclear facilities. Different from the USA, there is no legal obligation for nuclear operators to seek financial coverage for their onsite decontamination in Europe. EMANI was created by the nuclear industry to complement the insurance capacity. EMANI can either act as the leading underwriter or as a co-insurer to provide insurance directly, or act as a reinsurer. Since EMANI can act either as a leading underwriter or as a co-insurer with national pools, two different types of policies exist: the national pool policy and the EMANI policy. They may have different coverage and prices. See Liu (2013, pp. 227-228).

51 ELINI was created at the end of 2002 to provide insurance capacity for nuclear liability risks. It is the first worldwide nuclear pooling system aimed at providing nuclear third party liability coverage. There are three types of membership for ELINI: the insured members who have an insurance policy and have contributed to the constitution of the guarantee fund; non-insured members who take part in the constitution of the guarantee fund (supportive members) and non-insured members who do not take part in the constitution of the guarantee fund, but pay an administration fee. Both insured members and supportive members make annual contributions to the guarantee fund according to the agreed ratios. If the total losses exceed the contributions, an additional call can be made up to 20 times the annual contributions. For details, see Liu (2013, pp. 228-229). 
The pooling system established under the Price-Anderson Act of $1957^{52}$ in the USA is such an example. According to the Price-Anderson Act, each license issued should have and maintain financial guarantee to cover public liability claims. ${ }^{53}$ The term 'public liability' is defined as 'any liability arising out of or resulting from a nuclear incident', with the exceptions of claims arising out of an act of war, workmen's compensation claims, and claims for damage to onsite property at a licensed nuclear facility. ${ }^{54}$ The existing capacity of the insurance market (provided by a monopolistic national pool, American Nuclear Insurers, ANI) is $\$ 375$ million. If an accident creates damage in excess of $\$ 375$ million, a second layer of compensation needs to be provided: a retrospective premium will be called upon from all American nuclear operators licensed by the Nuclear Regulatory Commission (NRC). This premium is payable in annual instalments up to a certain maximum amount per incident per power plant and is determined according to the size and the number of reactors each plant has (Faure and Vanden Borre 2008, p. 243). The amount of this second tier is set at $\$ 121.255$ million, with a maximum annual retrospective premium of $\$ 18.963$ million per reactor per calendar year in $2016 .{ }^{55}$ If a catastrophic accident happens, which needs the collection of retrospective premiums in several years, the victims do not need to wait until the operators paid all the premiums. The NRC guarantees those retrospective premiums, or in other words, pre-finances the compensation in the second tier and later collects this from the operators (Faure and Vanden Borre 2008, p. 260).

This retrospective premium scheme was introduced in 1975. Initially, the financial requirement was satisfied with the coverage from private insurance and a government indemnity agreement. ${ }^{56}$ This was because it was regarded that the nuclear industry was not capable to bear all the burdens at its infancy period and the PAA intended to encourage the development of the nuclear industry. However, after years of development, it was believed that the industry should take its responsibilities. ${ }^{57}$ This was achieved by phasing out federal indemnity and establishing the system of retrospective premiums paid by nuclear operators.

Rather than the voluntary pooling of operators as in the case of most risk-sharing agreements, the retrospective premiums scheme is mandatory, and established according to the legislative requirement of the amended PAA. This arrangement ensures that all nuclear power plant operators participate in the system and provide strong capacity. Besides, this system is used only when the primary instrument - the insurance market fails to cover the full damage. In other words, the retrospective premiums scheme provides an upper layer of compensation for victims.

The retrospective premiums do not need to be paid ex ante, but are collected only when damage with a magnitude in excess of the primary coverage happens. Since the obligation of payment only comes due after the occurrence of damage, a special arrangement is

\footnotetext{
5242 U.S.C.A. Sect. 2210.

53 Pub.L. No. 85-256, 71 Stat. 576,577 (1957).

54 Pub.L. No. 85-256, 71 Stat. 576,576 (1957).

5510 C.F.R. Sect. 140.11 (4). The Price-Anderson Act requires 5\% surcharge in case a nuclear incident exceeds the financial protection required. This makes maximum retrospective premium reach $\$ 127.318$ million per reactor. Considering the number of operating reactors in the USA, this makes the total available compensation for each accident reach $\$ 13.2$ billion. See http://www.amnucins.com/insurance/sfp-policy/.

56 The 1957 Price-Anderson Act required nuclear operators to provide financial guarantee up to the maximal amount available from insurance market, which was $\$ 60$ million at that moment. The government provided indemnity in case of an accident in excess of the required financial protection. In total, the available amount of compensation was $\$ 500$ million. See Liu (2013, p. 236).

57 H.R.Rep.No. 94-648, 10.
} 
needed to ensure that the operators can pay their retrospective premiums in the case of damage. According to NRC regulations, the operators need to provide one of the following guarantees: surety bond, letter of credit, revolving credit/term loan arrangement, maintenance of escrow deposits of government securities, annul certified financial statement and other type of guarantee approved by NRC. ${ }^{58}$ According to NRC regulations, if an operator fails to pay the retrospective premium, NRC reserves the right to pay those premiums on behalf of the licensee and recover the amount from the operator (GAO 2004, p. 8).

The retrospective premiums are determined by the number of reactors, which limits the effect of risk differentiation. To ensure that reactors possess comparable levels of risks is hence very important. It can be achieved via the following ways. Firstly, the retrospective premium scheme only provides a second layer of compensation. The first layer is provided by insurance. The insurer ANI differentiates the risks of reactors by setting the premiums according to the reactor type, use, size, location, type of containment and the performance of reactors. ${ }^{59}$ Secondly, the NRC collects retrospective premiums and pre-finances the compensation in the second layer. It hence has an interest in controlling the risks of the reactors by, for example, safety regulation and requiring guarantees for the retrospective premiums. Thirdly, the self-regulatory institution, the Institute of Nuclear Power Operations (INPO) also plays a crucial role in risk monitoring and controlling.

\section{Policy analysis}

The above analysis shows some advantages of risk-sharing agreements in providing preventive incentives and in pooling a large amount of money for compensation. It can provide an alternative when commercial insurance fails to emerge due to the lack of information or associated high costs. The examples provided in the previous section showed, as was predicted in Sect. 2, that risk sharing is often able to reduce Calabresi's total costs of accidents. Primary cost reduction is possible since operators, such as the P\&I Clubs provide better information to aim at risk reduction. Secondary cost reduction is possible as risk sharing allows generating much higher amounts of compensation, like the explosion of a nuclear power plant. The retrospective pooling agreement under the PriceAnderson Act illustrates this. And the reduction of tertiary costs is possible to the extent that there is competition between the pools (such as between the P\&I Clubs) which gives incentives for cost reduction.

However, this does not mean that risk-sharing agreements can always emerge. The size of the pool is essential for the establishment of risk-sharing agreements. A large number of members can better spread the risks and make a large amount of compensation available. However, a large size may affect the capacity of members to conduct mutual monitoring. Under this situation, it is crucial to adopt measures to ensure the risks created by different members are comparable ${ }^{60}$ or to conduct risk differentiation. ${ }^{61}$ In addition, in case the potential amount of members to the pool would be quite high, the administrative costs of

\footnotetext{
58 10 C.F.R. Sect. 140.21.

59 See Liu (2013, p. 244).

${ }^{60}$ For example, the nuclear pool in the USA relies on the common public regulation and on self-regulatory institutions like INPO to ensure the comparability of risks.

61 For example, P\&I Clubs have established measures to evaluate the risks of vessels and decide the premiums accordingly. See supra Sect. 3.2.
} 
running the pool might be large, as a result of which pooling may lose some of its relative attractiveness, compared to insurance.

The theoretical advantages of a risk-sharing agreement (strong incentives for mutual monitoring) are only materialized if a risk differentiation is possible in the sense that higher risks pay effectively a much higher contribution than lower risks. Especially with 'low probability high damage' events, the relative difference between high and low risk operators may be too small in order to provide incentives for risk reduction.

Moreover, if the operators can at least rely on the fact that all members will have to comply with minimum safety regulations, their additional task of mutual monitoring will be relatively limited. Since such safety regulation is enforced in the USA (via the Nuclear Regulatory Commission), risk sharing is easier in the USA than in Europe where there was large reluctance given the absence of mandatory safety requirements. ${ }^{62}$

That may hence be an important lesson at the policy level: if the policymaker (like the EU Commission) would like to stimulate risk sharing by operators, it can play an important role in providing a facilitative strategy, i.e. providing minimum safety standards, thus reducing the need for very intensive mutual monitoring. In the absence of minimum safety standards, there will always be a risk of negative redistribution and adverse selection since the risk-sharing agreement will then be most attractive for the bad risks as a result of which the good risks will not be willing to join.

\section{Concluding remarks}

In this contribution, we have argued that risk pooling between operators has a few attractions and advantages, especially when risks are complicated, highly technical and relatively little information is available with third parties (more particularly insurers). Under those circumstances, insurance coverage may be problematic since insurance always requires ex ante information on the probability of an accident and the potential magnitude of the damage in order to be able to calculate actuarially fair premiums. ${ }^{63}$ In that respect, a pooling arrangement has the major advantage that coverage is possible without necessarily having actuarial correct information on risk, as long as the relative contribution of the different parties to the pool is known. Second, pooling is especially attractive since it will provide incentives for mutual monitoring. However, a crucial condition for a pooling arrangement to work effectively is that at least a minimum level of safety regulation exists. The compliance with minimum safety requirements reduces the risk of free-riding and the need for the operators themselves to exercise mutual monitoring. This explains why a pool emerged for property damage in the USA, but why so far a European pool for nuclear liability failed. Differently than in the USA (where minimum safety standards are enforced via the nuclear regulatory commission), minimum safety standards in the nuclear area are largely absent in Europe. An important lesson from these examples is hence that the regulator can play an important role in facilitating pooling mechanisms by introducing safety regulation that guarantees a minimum level of safety. This may be an important condition to support a pooling mechanism, for environmental risks, like those related to the offshore sector.

\footnotetext{
${ }^{62}$ In Europe, the countries with nuclear installations have varying political, legal and economic background, which creates a challenge for international pooling. For details, see Skogh (2008).

63 See supra Sect. 2.2.
} 
Moreover, since a pooling mechanism is based on mutual trust, as long as financial guarantees to back up the solvency of the members exist, contributions should not necessarily be paid ex ante. This may be quite important since contributions to be paid ex ante may lead to a substantial immobilization of capital and hence restrict the economic development of the sector. We discussed a few examples, where ex post pooling systems are in place based on retrospective premiums. In other words, there is no need to ex ante pay contributions (and thus immobilize capital which otherwise could be used to increase social welfare). Contributions only need to be paid ex post via retrospective premiums.

Those examples all show that risk sharing may have the potential to step in where traditional insurance markets (precisely because of information asymmetry with operators) may fail to provide cover. In that case, risk-sharing agreements may not only provide efficient incentives for prevention (via mutual monitoring) but equally generate relatively high amounts of compensation (especially when it is constructed via a retrospective pooling scheme). Therefore, where increasingly (e.g. also in the Offshore Safety Directive ${ }^{64}$ ) obligations are imposed upon operators to show financial cover, authorities should not only look at traditional (re)insurance as mechanism to fulfil this duty. As we have shown, also risk sharing between operators may well be able to provide evidence of solvency guarantees. Especially since evermore new environmental risks are created (resulting from, e.g. fracking, carbon capture and sequestration, nanotechnology, genetically modified organisms) traditional insurance markets may increasingly be reluctant to cover those largely unknown risks (on which little statistical information is available) as a result of which, also in the future, risk-sharing agreements may be playing an important role in preventing and compensating environmental damage.

However, it is worth noting that risks-sharing agreements have also their limitations. Mutual monitoring, risk differentiation and thus efficient pooling are only possible if the differences in contribution between high- and low-risk operators are substantial in order to indeed provide efficient incentives for prevention. If that were not the case, a risk of freeriding and moral hazard emerges as a result of which the low risk operators may not wish to join the pool, fearing that they will have to cross-subsidize high-risk operators. In this respect, mandatory safety regulation by the government can play an important role. If safety regulation could enforce compliance with high safety standards from all operators in the market, this could substantially reduce free-riding risks and thus stimulate the creation of risk-sharing agreements.

Funding Funding was provide by the Humanities and Social Science Foundation of Ministry of Education of China (Grant No. 14YJC820033), the Fundamental Research Funds for the Central Universities

\section{References}

Adelman, D. E., \& Duncan, I. J. (2011). The limits of liability in promoting safe geologic sequestration of CO2. Duke Environmental Law \& Policy Forum, 22(1), 1-66.

Ameye, E. (2010). Channeling of nuclear third party liability towards the operator: Is it sustainable in a developing nuclear world or is there a need for liability of nuclear architects and engineers? European Energy and Environmental Law Review, 19(1), 33-58.

Anderson, D. (1998). Development of environmental liability risk management and insurance in the United States: Lessons and Opportunities. Risk Management \& Insurance Review, 2(1), 1-23.

${ }^{64}$ Directive 2013/30 EU of 12 June 2013 on safety of offshore oil and gas operations, OJ L178/66 of 28 June 2013. 
Beck, U. (1992a). Risk society: Towards a new modernity (Vol. 17). Newcastle upon Tyne: Sage.

Beck, U. (1992b). From industrial society to the risk society: Questions of survival, social structure and ecological enlightenment. Theory, Culture \& Society, 9(1), 97-123.

Bennett, P. (2000). Mutuality at a distance? Risk and regulation in marine insurance clubs. Environment and Planning A, 32(1), 147-163.

Bennett, P. (2001). Mutual risk: P\&I insurance clubs and maritime safety and environmental performance. Marine Policy, 25(1), 13-21.

Bocken, H. (2009). Alternative financial guarantees for environmental liabilities under the ELD. European Energy and Environmental Law Review, 18(3), 146-170.

Bode, S., \& Jung, M. (2006). Carbon dioxide capture and storage-Liability for non-permanence under the UNFCCC. International Environmental Agreements: Politics, Law and Economics, 6(2), 173-186.

Bosma, S. (2012). The regulation of marine pollution arising from offshore oil and gas facilities-an evaluation of the adequacy of current regulatory regimes and the responsibility of states to implement a new liability regime. Australia and New Zealand Maritime Law Journal, 26, 89.

Calabresi, G. (1970). The cost of accidents: A legal and economic analysis. New Haven: Yale University Press.

Carroll, S. (2008). Perspective on the pros and cons of a pooling-type approach to nuclear third party liability. Nuclear Law Bulletin, 2008(1), 75-97.

Croley, S. P., \& Hanson, J. D. (1995). The nonpecuniary costs of accidents: Pain-and-suffering damages in Tort law. Harvard Law Review, 108(8), 1785-1917.

Doucette, J. E. (2002). Wading in the pool: Interlocal cooperation in municipal insurance and the state regulation of public entity risk sharing pools-A survey. Connecticut Insurance Law Journal, 8(2), 533-568.

Faure, M. G. (2004). Alternative compensation mechanisms as remedies for uninsurability of liability. The Geneva Papers on Risk and Insurance. Issues and Practice, 29(3), 455-489.

Faure, M. (2016). Liability and compensation for damage resulting from $\mathrm{CO}_{2}$ storage sites. William \& Mary Environmental Law \& Policy Review, 40(2), 387-476.

Faure, M., \& Grimeaud, D. (2003).Financial assurance issues of environmental liability.In Detterence, insurability, and compensation in environmental liability: Future development in the European Union (pp. 7-256). Vienna: Springer.

Faure, M., \& Bruggeman, V. (2008). Catastrophic risks and first-party insurance. Connecticut Insurance Law Journal, 15(1), 1-52.

Faure, M. G., \& Fiore, K. (2008). The coverage of the nuclear risk in Europe: Which alternative? The Geneva Papers on Risk and Insurance-Issues and Practice, 33(2), 288-322.

Faure, M., \& Hartlief, T. (2003). Insurance and expanding systemic risks. Paris: OECD.

Faure, M., \& Liu, J. (2012). The Tsunami of March 2011 and the subsequent nuclear incident at Fukushima: Who compensates the victims. The William \& Mary Environmental Law and Policy Review, 37(1), 129-218.

Faure, M., Liu, J., \& Wang, H. (2015). A Multilayered Approach to Cover Damage Caused by Offshore Facilities. Virginia Environmental Law Journal, 33, 356-422.

Faure, M. G., \& Skogh, G. (1992). Compensation for damages caused by nuclear accidents: A convention as insurance. Geneva Papers on Risk and Insurance: Issues and Practice, 17(65), 499-513.

Faure, M. G., \& Vanden Borre, T. (2008). Compensating nuclear damage: A comparative economic analysis of the US and international liability schemes. William \& Mary Environmental Law \& Policy Review, 33(1), 219-286.

Faure, M., \& Wang, H. (2015). Compensating victims of a European deepwater horizon accident: OPOL revisited. Marine Policy, 62, 25-36.

GAO. (2004). Report to congressional requesters, nuclear regulation: NRC's liability insurance requirements for nuclear power plants owned by limited liability companies, 8 .

Hazelwood, S. J., \& Semark, D. (2010). P\&I clubs: Law and practice. London: Lloyd's List.

Hogarth, R. M., \& Kunreuther, H. (1985). Ambiguity and insurance decisions. American Economic Review, 75(2), 386-390.

Katzman, M. T. (1986). Pollution liability insurance and the internationalization of environmental risks. Review of Policy Research, 5(3), 614-623.

Klass, A. B., \& Wilson, E. J. (2008). Climate change and carbon sequestration: Assessing a liability regime for long-term storage of carbon dioxide. Emory Law Journal, 58(1), 103-180.

Libby, G. E. (1952). Some aspects of protection and indemnity insurance. Insurance Law Journal, 1952(10), 684-709.

Liu, J. (2013). Compensating ecological damage: Comparative and economic observations. Cambridge: Intersentia. 
Pelzer, N. (2007). International pooling of operators' funds: An option to increase the amount of financial security to cover nuclear liability? Nuclear Law Bulletin, 2007(1), 37-55.

Priest, G. L. (1987). The current insurance crisis and modern Tort Law. Yale Law Journal, 96(7), 1521-1590.

Ronneberg, N. J. (1990). An introduction to the protection \& indemnity clubs and the marine insurance they provide. University of San Francisco Maritime Law Journal, 3, 1-36.

Shavell, S. (1979). On moral hazard and insurance. Quarterly Journal of Economics, 93(4), 541-562.

Shavell, S. (1984). Liability for harm versus regulation of safety. The Journal of Legal Studies, 13(2), 357-375.

Shrivastava, P. (1995). Ecocentric management for a risk society. Academy of Management Review, 20(1), $118-137$.

Skogh, G. (1999). Risk-sharing institutions for unpredictable losses. Journal of Institutional and Theoretical Economics (JITE), 155(3), 505-515.

Skogh, G. (2008). A European nuclear accident pool. The Geneva Papers on Risk and Insurance-Issues and Practice, 33(2), 274-287.

Visscher, L. T. (2009). Tort damages. In M. Faure (Ed.), Tort law and economics (pp. 153-200). Cheltenham/Northampton: Edward Elgar.

Wagner, G. (2007). (Un)insurability and the choice between market insurance and public compensation systems. In W. H. Van Boom \& M. Faure (Eds.), Shifts in compensation between private and public systems (pp. 87-112). Wien: Springer Vienna.

Wagner, G. (2009). Tort law and liability insurance. In M. Faure (Ed.), Tort law and economics (pp. 377-405). Cheltenham/Northampton: Edward Elgar.

Wilson, E. J., Johnson, T. L., \& Keith, D. W. (2003). Regulating the ultimate sink: Managing the risks of geologic CO2 storage. Environmental Science and Technology, 37(16), 3476-3483.

Wilson, E. J., Klass, A. B., \& Bergan, S. (2009). Assessing a liability regime for carbon capture and storage. Energy Procedia, 1(1), 4575-4582.

Zhu, L. (2007). International convention on civil liability for bunker oil pollution damage, 2001: Liability and insurance aspects. In J. Basedow \& U. Magnus (Eds.), Pollution of the Sea: Prevention and Compensation (pp. 171-180). Berlin: Springer-Verlag. 